\title{
Three new species of Heteragrion Selys, from Brazil with redescription of the holotype of $H$. Dorsale Selys (Odonata, Megapodagrionidae)
}

\author{
Angelo B. M. Machado
}

Departamento de Zoologia, Instituto de Ciências, Biológicas, Universidade Federal de Minas Gerais. Caixa Postal 486, 31270-901 Belo Horizonte, M inas Gerais, Brasil. E-mail: angelo@icb.ufmg.br

\begin{abstract}
Heteragrion luizfelipei sp. nov. from Santa Catarina, Heteragrion gracile sp. nov. from Minas Gerais) and Heteragrion mantiqueirae sp. nov. from São Paulo are described and illustrated. The color and structural characters that distinguish these species from those of Selys group 2 are discussed. The holotype of Heteragrion dorsale Selys, 1862 is redescribed and illustrated.
\end{abstract}

KEY WORDS. Damselfly; Zygoptera; taxonomy; type specimen.

RESUMO. Três espécies novas de Heteragrion Selys do Brasil com redescrição do holótipo de $\boldsymbol{H}$. dorsale Selys (Odonata, Megapodagrionidae). Heteragrion luizfelipei sp. nov. de Santa Catarina, Heteragrion gracile sp. nov. de Minas Gerais e Heteragrion mantiqueirae sp. nov. de São Paulo são descritos e ilustrados. São descritos os caracteres estruturais e de cor que distinguem essas espécies daquelas descritas no grupo 2 de Selys. O holótipo de Heteragrion dorsale Selys, 1862 é redescrito e ilustrado.

PALAVRAS-CHAVE. Libélula; Zygoptera; taxonomia; espécime-tipo.

Erected by SELYS (1862) the genus Heteragrion was reviewed by Williamson (1919) who described and listed 29 species. At the same time SJösteDt (1918) and Rıs (1918) described seven species. Only fourty seven years later another species was described, by Donnely (1965). As concerns the species originally described from Brazil, Selys (1886) described H. obsoletum Selys, 1886 and, only 102 years later (MACHADO 1988), appeared the description of another Brazilian species, $\mathrm{H}$. petiense Machado, 1988 followed by H. muryense Costa \& Santos, 2000. These enormous gaps in Heteragrion descriptions cannot be explained by its rareness, for the species of the genus are not difficult to find in the field and are abundant in collections. It can be better explained by the difficulty in establishing the identity of many species, in special those of Selys group 2, so far described with vague and incomplete data, with innacurate or entirely missing illustrations. This situation has prompted studies of the types of these species, as already done by De Marmels (1987, 2004) for Sjöstedt species and for $\mathrm{H}$. macilentum Hagen in Selys, 1862 and by WILLIAMSON (1919) for some of Selys and Hagen species. Following the same research line, we now redescribe the holotype of $\mathrm{H}$. dorsale Selys, 1862 borrowed from Sely's collection at Brussels and hitherto know only from Selys description. Wealso describethree new species of Heteragrion from South and Southeastern Brazil. With them, the number of known species of Heteragrion goes to 46, 20 of which from the Brazilian fauna.

\section{Heteragrion Iuizfelipei sp. nov.}

Figsl, 2, 5, 6, 9, 10, 13, 14

Holotype male. Head (Fig. 1). Color names according to KoRNERUP \& W ANSCHER (1967). Labium yellowish white, labrum ligth orange, base of mandibles and genae yellowish; anteclypeus brown, postclypeus light orange with an hourglassshaped black spot connected to a black line at the frontoclypeal suture (Fig. 1). Anterior portion of frons orange with a narrow triangular black mark that meets the black line of the frontoclypeal suture. Top of head (Fig. 1) orange with the following black marks: a triangular black spot in the middle of the posterior portion of frons; a subtriangular spot surrounding the median ocellus, connected laterally to an oblong spot situated medially to the antennae base; a curved spot laterally to the antennae base; a small triangular spot adjacent to the eye; a transverse occipital bar connected anteriorly to the black area encircling the lateral ocelli (Fig. 1). Rear of the head yellowish white.

Thorax. Prothorax (Figs 5 and 9). Propleuron yellow. Anterior pronotal lobe black, laterally orange; median pronotal lobe greyish orange; posterior pronotal lobe orange with a large round black spot in the midle and a black lateral line on its limit with the median lobe. Pterothorax (Figs 5-9): mesepisternum orange with the middorsal, antealar and basal carinae black, the latter distally orange; antealar sinus and acrotergal

Revista Brasileira de Zoologia 23 (4): 1062-1070, dezembro 2006 
area (COSTA 1978) yellow; mesepimeron and metepisternum yellowish orange, the former with a large black stripe occupying almost the entire width of the sclerite, however narrowing above and not reaching its upper part of the sclerite (Fig. 9); metepimeron yellowish white with a slight greenish tinge on its hind and ventral parts. Legs brownish yellow. Wings hyaline, veins black, pterostigma trapeze-shaped, dark brown. Venation. Postnodals in forewing 17 (9.0\%), 18 (36.3\%), 19 (27.3\%), 20 (27.3\%); in hindwing 15 (27.3\%), 16 (27.3\%), 17 (18.1\%), 18 (27.3\%); postquadrangular cells in fore and hindwings 2 (100.0\%); number of cells bellow the pterostigma in forewing $2(18.8 \%), 21 / 2(72.7 \%), 1 / 2+1+1 / 2(9.0 \%)$; in hindwing 2 (27.3\%), 2 1/2 45.4\%), $1 / 4+2+1 / 4$ (9.0\%), $1 / 2+$ $1+1 / 2(18.8 \%)$. Fore and hindwings petiolated beyond the base of the quadrangle.

Abdomen. Segments 1-2 laterally pal eyellow with a slight greenish tinge, dorsally black with a middorsal yellow line. Segments 3-7 four banded i.e. with a proximal yellow ring followed by a long black area, then by an area with lateral yellow streaks, then by a black distal area. Segment 8 black with a ventrolateral brownish orange stripe and a distal ring of the same color occupying its distal 1/4. Segment 2-8 with a middorsal yellow longitudinal line; 9-10 brownish orange, 10 with a dorsal dark brown area and a middorsal black keel. Superior appendages black, except for a basomedial yellowish area.

Structural characters. Posterior prothoracic lobe smoothly convex (Fig. 5). Superior anal appendages, in lateral view (Fig. 14) slightly swollen ventrally at base, this part hollow. In dorsal view (Fig. 13) forcipated with the apex of the medial process at $1 / 2$ of the appendage length, two-tipped. The tips correspond to the dorsal and ventral tooth that are partially overlapped, the dorsal one with the border finely denticulated. Border of basoventral lobe virtually devoid of hairs. Inferior appendage absent.

Measurements $(\mathrm{mm})$. Abdomen (with appendages) 36.740.0 (mean 38.8); maximum width (segment 9) 1.5; minimum width 0.6; hindwing 25.5-29.5 (mean 26.1); pterostigma hindwing (radial side) 1.9-2.1 (mean 2.0).

Allotype female. Head (Fig. 2). Iabium yellowish white, labrum orange, mandible base, genae and anteclypeus light orange; postclypeus black with large, lateral light orange spot at each side; frons orange with a median triangular black spot on its anterior portion connected with another triangular black area on the posterior portion (Fig. 2). Top of head ligth orange, with black marks as follows: a narrow occipital stripe; a subrectangular spot touching the eye; two large oblong marks connected with each other behind the median ocellus, each one encircling the anterior portion of the antennae base, a triangular spot between the antennae base and the eye. A ring encircling the lateral ocelli, missing in one paratype and connected with the occipital stripe in another. Rear of the head yellowish white.

Thorax. Prothorax (Figs 6 and 10) grayish orange, black at the rim of the anterior lobe and at a round spot in the middle of the posterior lobe that is convex. Pterothorax grayish orange with black marks as follows (Figs 6 and 10): at the middorsal, antealar and basal carinae extending below to the acrotergal area; a narrow stripe adjoining the middorsal carina at each side; a stripe parallel to that of middorsal separated from it by a pale area; a stripe in the middle of the mesepimeron not reaching the upper and lower parts of the sclerite (Fig. 10). Legs, femorae and tibiae greyish orange, tarsi orange brown. Wings hyaline, veins brown, pterostigma trapeze-shaped, yellowish brown. Venation. Postnodals in forewing 17 (16.6\%), $18(66.6 \%), 19$ (16.6\%); postnodals in hindwing 16 (50.0\%), 17 (16.6\%), 18 (33.3\%); postquadrangular cells in fore and hindwings $2(100 \%)$; number of cells below the pterostgma in forewing 2 (16.6\%), 2 1/2 (50\%), 2 - 1 - 1/2 (16.6\%), 1/2 - 1 2/3 (16.6\%); in hindwing 2 (33.3\%), $21 / 4$ (16.6\%), $21 / 2$ (33.3\%), $1 / 2-1-1 / 2$ (16.6\%).

Abdomen. Segments 1-2 greyish orange, dorsally black, 3-7 four banded i.e. with a proximal yellow ring followed by a long black area, then followed by an area with lateral orange white streaks, then which in turn is followed by a black distal area, 8-10 orange white with the dorsum brown in its whole extension (8) or only on half its extent (9-10). In all abdominal segments except 9-10 there is a middorsal yellow longitudinal line. Ovipositor orange white. Appendages dark brown.

Measurements (mm). Abdomen 30-35.5 (mean 32.7); hindwing 24.0-28.4 (mean 25.6); hindwing pterostigma (radial side) 2.0-2.2.

Material examined. Holotype male, Brazil, Santa Catarina: Urubuci (1.300 m), 15-I-2005, P.A. Machado \& M. B. Machado leg. Allotype female, Joinville, 12-XII-1981, Miers leg. Paratypes: same locality and collector as holotype, 6 males; same locality and collector as the allotype, 5 females, Joinville, 1 male 16XI-79. Paraná, Guaraqueçaba, 8-3-1988, P.A. Machado leg. Holotype, allotype, 7 males and 5 females, paratypes deposited in A.B.M. Machado collection in Belo Horizonte, Minas Gerais, Brazil, 1 male and 1 female paratypes deposited in the Entomological Collection of the Taxonomic Collection of the Universidade Federal de Minas Gerais, Belo Horizonte, Brazil.

Etymology. The species is named after my grandson Luiz Felipe Machado Haertel.

Remarks. Heteragrion luizfelipei belongs in the species group 2 of SelYs (1862) and keys out to couplet $C^{1}$ of WILLIAM SON'S (1919) key for males along with Heteragrion triangulare Selys, 1862 and $\mathrm{H}$. beschkii Hagen in Selys, 1862. It differs from $\mathrm{H}$. triangulare mainly by lacking the mesepisternal black stripe observed in this species. It differs from $\mathrm{H}$. beschkii mainly by having the posterior prothoracic lobe with a large round black spot that is absent in $\mathrm{H}$. beschkii. It is also quite different from the male of $\mathrm{H}$. dorsale, whose overall color is black whereas in $\mathrm{H}$. luizfelipei it is orange and yellow. Heteragrion luizfelipei differs from $\mathrm{H}$. macilentum whose lectotype has been recently illustrated (DE MARMELS 2004) by having the posterior protho- 

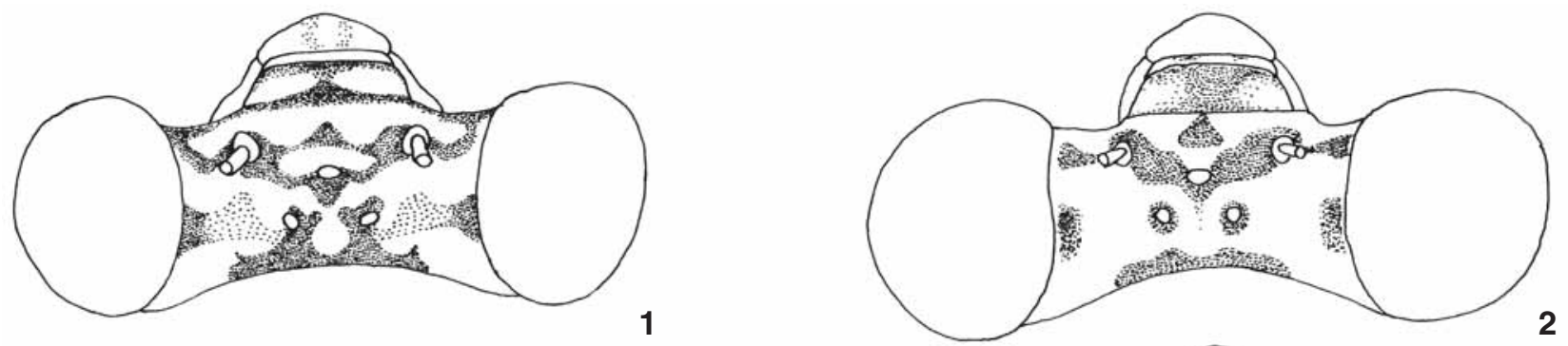

1

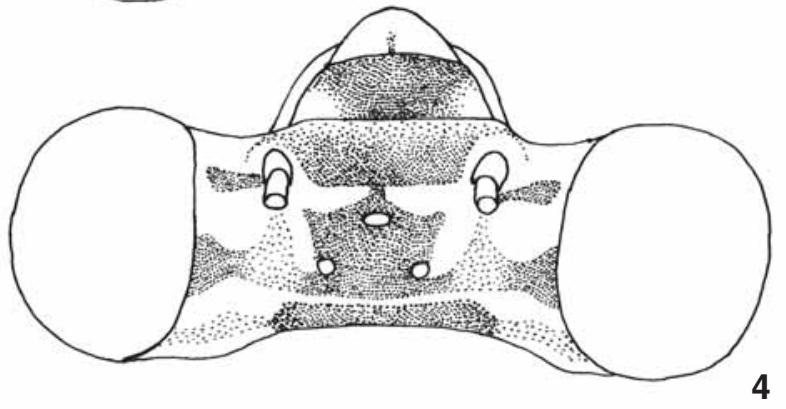

3
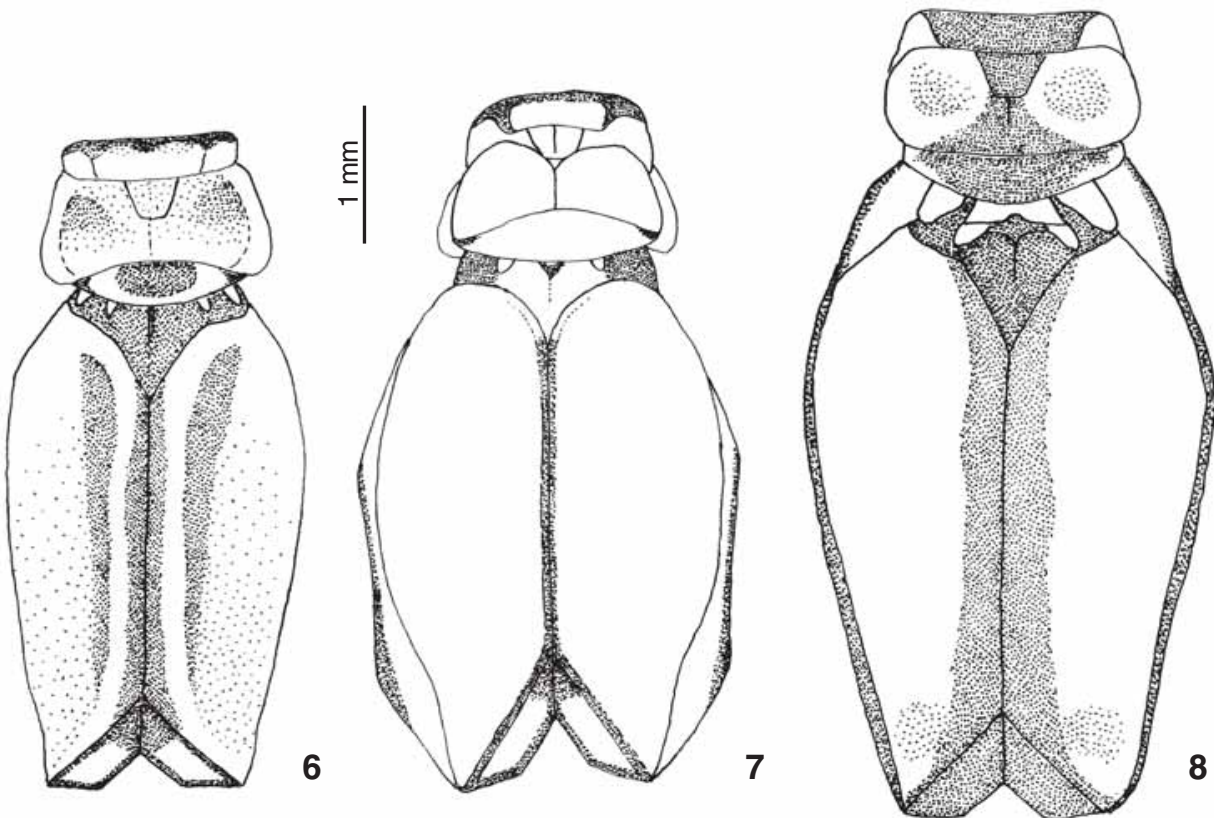

Figures 1-8. (1-4) Top of head in the holotype male (1) and allotype female (2) of H. luizfelipei and the male holotypes of H. gracile (3) and $\mathrm{H}$. mantiqueirae (4); (5-8) thorax in dorsal view of the holotype male (5) and female allotype (6) of H. luizfelipei and the holotypes male of $\mathrm{H}$. gracile (7) and $\mathrm{H}$. mantiqueirae (8).

racic lobe with a large round black spot (pale throughout in macilentum) and the medial process of the superior appendages two-tipped (one-tipped in $\mathrm{H}$. macilentum). Besides, the top of head is dominantly pale in $\mathrm{H}$. Iuizfelipei and dominantly blackish in $\mathrm{H}$. macilentum. The differences between the male of H. luizfelipei sp. nov. and H. ochraceum Hagen in Selys, 1862 are more difficult to evaluate in view of the uncertainties about the male type specimen of $\mathrm{H}$. ochraceum and lack of a good description of it. Indeed all the information available about the male of this species is contained in four lines in which its differences from $\mathrm{H}$. beschkii are pointed out by SELYS (1862). These information were used in tablel that also shows the main 
differences between the males of $\mathrm{H}$. luizfelipei and those of $\mathrm{H}$. gracile sp. nov., $H$. mantiqueirae sp. nov., $H$. ochraceum and $H$. dorsale. Curiously, the female of $\mathrm{H}$. ochraceum has been better described than the male. WILLIAMSON (1919) examined and illustrated the head color pattern of the female specimen in Hagen's collection, regarded by him as being the one on which the description by SELYS (1862) was based. The differences between the female of $\mathrm{H}$. luizfelipei and that of $\mathrm{H}$. ochraceum are shown in table II. Taken together, the differences observed be tween the males and females of $\mathrm{H}$. Iuizfelipei and those of ochraceum leave no doubt that they are specifically distinct.

\section{Heteragrion gracile sp. nov.}

Figs $3,7,11,15,16$

Holotype male. Head (Fig. 3). Labium orange white, Iabrum orange, base of mandibles, genae, anteclypeus and postclypeus grayish orange, the latter with a very narrow transverse black mark posteriorly. Anterior portion of frons and top of head grayish orange with black marks as follows (Fig. 3): an anteromedial subtriangular spot at the posterior part of frons; a triangular spot between the antennae base and the eye with the tip directed to the antennae; a small subtriangular spot situated medially to the antennae bases; a round mark encircling the medial ocellus; a narrow occipital stripe connected with the lateral ocelli. Rear of the head orange white.

Thorax (Figs 7 and 11). Prothorax grayish orange except for the rim and lateral extremity of the anterior lobe and a dot at the lateral extremity of the posterior lobe that are black. Pterothorax (Figs 7 and 11): mesepisternum grayish orange; middorsal and antealar carinae black; basal carinae grayish orange; antealar sinus and acrotergal area (COSTA 1978) grayish orange. A black spot around the anterior thoracic spiracles and an elongated brownish orange mark on the mesinfrepisternum (Fig. 11), central part of the metepimeron with an elongated black stripe (Fig. 11); metapleuron grayish orange except for the ventral part of metepimeron that is orange white. Legs light brown. Wings hyalin, venation brown, pterostigma brownish orange. Venation. Postnodals in forewing 20; in hindwing 17; postquadrangular cells in forewing 2; in hindwing 2. Number of cells below the pterostigma; in forewing $21 / 2$; in hindwing 2; foreand hindwings petiolated beyond the base of the quadrangle.

Abdomen. Segments 1-2 laterally orange white, dorsally grayish orange with a middorsal pale line. Segments 3-6 four banded i.e. with a proximal light orange ring, followed by a long dark area, then followed by a grayish orange area, then by which in turn is followed by a black distal area. Segment 7 black with a lateroventral grayish orange area at its distal fourth. Segment 8 grayish orange, ventro-lateraly black with a proximal black ring occupying its proximal third. Segments 9-10 grayish orange, the latter with a small dark brown area at each side of a black middorsal keel. Superior anal appendages laterally black, medially grayish orange. Inferior appendages lacking.

Structural characters. Posterior prothoracic lobe smoothly convex (Fig. 7). Superior anal appendages in lateral view (Fig. 16) slightly swollen ventrally at base, this part hollow. In dorsal view (Fig. 15) forcipated with the apex of the medial process at 2/3 of the appendage length, smoothly curved, its ventrobasal lobe with the border hairy (Fig. 15). Inferior appendages absent.

Measurements (mm). Abdomen (with appendages) 42.3, abdomen maximum width (segment 9) 1.5; abdomen minimum width (segment 4) 0.4; hindwing 30.4; pterostigma hindwing (radial side) 1.5.

Material examined. Holotype male. BrAZIL, Minas Gerais: Carmo do Rio Claro, 15.I.1984, José Augusto Barbosa leg., deposited in collection A.B.M. Machado, Belo Horizonte, Minas Gerais, Brazil.

Female. Unknown.

Etymology. gracile, from the latin slender, an allusion to the fact that it is a very slender species.

Remarks. Heteragrion gracile belongs in the species group 2 of SELYS (1862) and keys out to H. beschkii in WiLLIAMSON'S (1919) key. It differs from $\mathrm{H}$. beschkii mainly by the extent of the head's black areas that is subequal to that of the pale ones in $\mathrm{H}$. beschkii, whereas in $\mathrm{H}$. gracile the pale colors dominate. Besides, the pattern of the head's black marks in $\mathrm{H}$. beschkii is very different from that in $\mathrm{H}$. Iuizfelipei. In order to compare the thorax of $\mathrm{H}$. gracile with that of $\mathrm{H}$. beschkii we have to rely on the information made available by SelYs $(1860,1877)$. When treating the differences between $\mathrm{H}$. beschkii and $\mathrm{H}$. aurantiacum Selys, 1877 states that $\mathrm{H}$. beschkii differs from $\mathrm{H}$. aurantiacum mainly by having the dorsal black stripe of the anterior part of the pterothorax larger than that of $\mathrm{H}$. aurantiacum. The presence of this black stripe in $\mathrm{H}$. beschkii is an important character to distinguish it from $\mathrm{H}$. gracile, whose mesepisternum has no black stripe at all. Heteragrion gracile differs from $\mathrm{H}$. macilentum, whose lectotype has been recently illustrated by De Marmels (2004) mainly by having the postclypeus, anterior portion of frons and top of head grayish orange whereas in $\mathrm{H}$. macilentum these are dominantly blackish. Moreover, the medial process of the superior appendages of $\mathrm{H}$. gracile are smoothly curved, while in $\mathrm{H}$. macilentum these are truncated. The differences between $\mathrm{H}$. gracile, $\mathrm{H}$. ochraceum and $\mathrm{H}$. dorsale, as well as between the other two species herein described are shown in table I.

\section{Heteragrion mantiqueirae sp. nov.}

Figs 4, 8, 12, 17, 18

Holotype male. Head (Fig. 4). Labium orange white, labrum orange with a central brownish dot; base of mandibles, genae and anteclypeus light orange, the latter with two brownish orange spots; postclypeus black with light orange lateral spot at each side. Anterior portion of frons brownish orange with a triangular black spot in the middle. An oblique transverse brown stripe between the anterior portion of frons and the eye. Posterior portion of frons black. Remainder parts of the epicranium orange, or brownish orange in the area situ- 
Table I. Characters separating the males of the new species herein described from those of $\mathrm{H}$. ochraceum and $\mathrm{H}$. dorsale.

\begin{tabular}{|c|c|c|c|c|c|}
\hline Characters & H.luizfelipei sp. nov. & H.gracilis sp. nov. & H. mantiqueirae sp. nov. & H. ochraceum & H. dorsale \\
\hline Labrum & $\begin{array}{l}\text { Light orange } \\
\text { throughout }\end{array}$ & $\begin{array}{l}\text { Orange } \\
\text { throughout }\end{array}$ & $\begin{array}{l}\text { Orange with a small } \\
\text { brownish central area }\end{array}$ & $\begin{array}{l}\text { Pale with the } \\
\text { basal third black }\end{array}$ & $\begin{array}{l}\text { Orange with a black } \\
\text { basal central dot }\end{array}$ \\
\hline Middle of prothorax & Orange & Orange & Black & Black & Black \\
\hline Posterior prothoracic lobe & $\begin{array}{l}\text { Orange with a large } \\
\text { round black spot }\end{array}$ & $\begin{array}{l}\text { Grayish orange } \\
\text { without black spot }\end{array}$ & Virtually black & $\begin{array}{l}\text { Pale with a central } \\
\text { black spot }\end{array}$ & Black \\
\hline Antealar sinus & Yellow & Grayish orange & Black & - & Black \\
\hline Acrotergal area & Yellow & Grayish orange & Black & Black & Black \\
\hline $\begin{array}{l}\text { Black stripe adjoining the } \\
\text { middorsal carinae }\end{array}$ & Absent & Absent & Present $(0.5 \mathrm{~mm}$ wide) & - & Absent \\
\hline $\begin{array}{l}\text { Dominant color on top of } \\
\text { head }\end{array}$ & Orange & Orange & $\begin{array}{l}\text { Orange subequal to } \\
\text { black }\end{array}$ & - & Black \\
\hline $\begin{array}{l}\text { Medium process of } \\
\text { appendages }\end{array}$ & Two tipped & Smoothly round & Smootly round & - & - \\
\hline $\begin{array}{l}\text { Base to apex of medial } \\
\text { process in relation to } \\
\text { appendage length }\end{array}$ & At $1 / 2$ length & At $2 / 3$ length & At $3 / 5$ length & - & - \\
\hline $\begin{array}{l}\text { Extent of pale area in male } \\
\text { abdominal segment } 8\end{array}$ & Distal $1 / 4$ & Distal 2/3 & Distal half & - & - \\
\hline $\begin{array}{l}\text { Basoventral lobe of } \\
\text { superior appendage }\end{array}$ & $\begin{array}{l}\text { Virtually devoid of } \\
\text { hairs }\end{array}$ & $\begin{array}{l}\text { With the margin } \\
\text { hairy }\end{array}$ & With the margin hairy & - & - \\
\hline
\end{tabular}

Table II. Characters separating the females of H. luizfelipei from those of H. ochraceum.

\begin{tabular}{lll}
\hline \multicolumn{1}{c}{ Characters } & \multicolumn{1}{c}{ H. luizfelipei } & \multicolumn{1}{c}{ H. ochraceum } \\
\hline Labrum & Orange throughout & Yellow with the anterior border largely black \\
Transverse black band on the posterior portion of frons & Absent & Present \\
Oblong mark between the antennae base and a median ocellusPresent & Absent \\
Anterior prothoracic lobe & With black rim & With yellow rim \\
Acrotergal area & Black & Yellow \\
Black mesepimeral stripe & Not bordered with yellow Bordered with yellow at each side \\
\hline
\end{tabular}

ated between the frons and the ocellar region, with the following black or brownish marks (Fig. 4). A squarish black area at the ocellar region connected with the black frontal area by a black line. From the posterolateral corner of this squarish area stems a narrow black stripe with an anterior dark brown branch to the antennae base and a medially dark brown, laterally black branch to the eye. A black elongated spot between the antennae base and the eye. An occipital stripe separated from the squarish black area by a narrow orange line; a brownish elongated transverse postocular mark. Rear of the head orange white.

Thorax. Prothorax (Figs 8 and 12). Propleuron light orange. Anterior lobe largely black except for a light orange mark at its lateral extremity; median lobe dorsolaterally brownish orange, medially black; posterior lobe largelly black except for a small lateral elongated brownish orange spot, reduced to a dot in the paratype. Pterothorax (Figs 8 and 12): mesepisternum largely orange on the holotype, light orange on the paratype. Middorsal, antealar and basal carinae black. A black dorsal stripe adjoining the middorsal carinae at each side, $0.5 \mathrm{~mm}$ wide at midlength, slightly narrower $(0.4 \mathrm{~mm})$ bellow, continuing above into the antealar sinus and below into the acrotergal area (COSTA 1978). A brownish orange spot at the upper part of the mesepisternum. A large mesepimeral black stripe $(0.9 \mathrm{~mm}$ at midlength) occupying virtually the whole extent of the sclerite, turning into brownish orange below, continuing into the mesinfrepisternum (Fig. 12). Metepisternum and lateral part of the metepimeron with translucent areas, and somewhat elusive brownish orange stripes more evident on the metepisternum. This metepisternal stripes becomes more evident after 2-3 minutesillumination with thestereo microscopeilluminator, fading when thelight isturned off. Ventral part of metepimeron light orange with large translucent areas. In the paratype all the metapleuron is translucent with light orange areas and no trace of stripes. Legs brown. Wings hyaline, venation brown, pterostigma brownish 

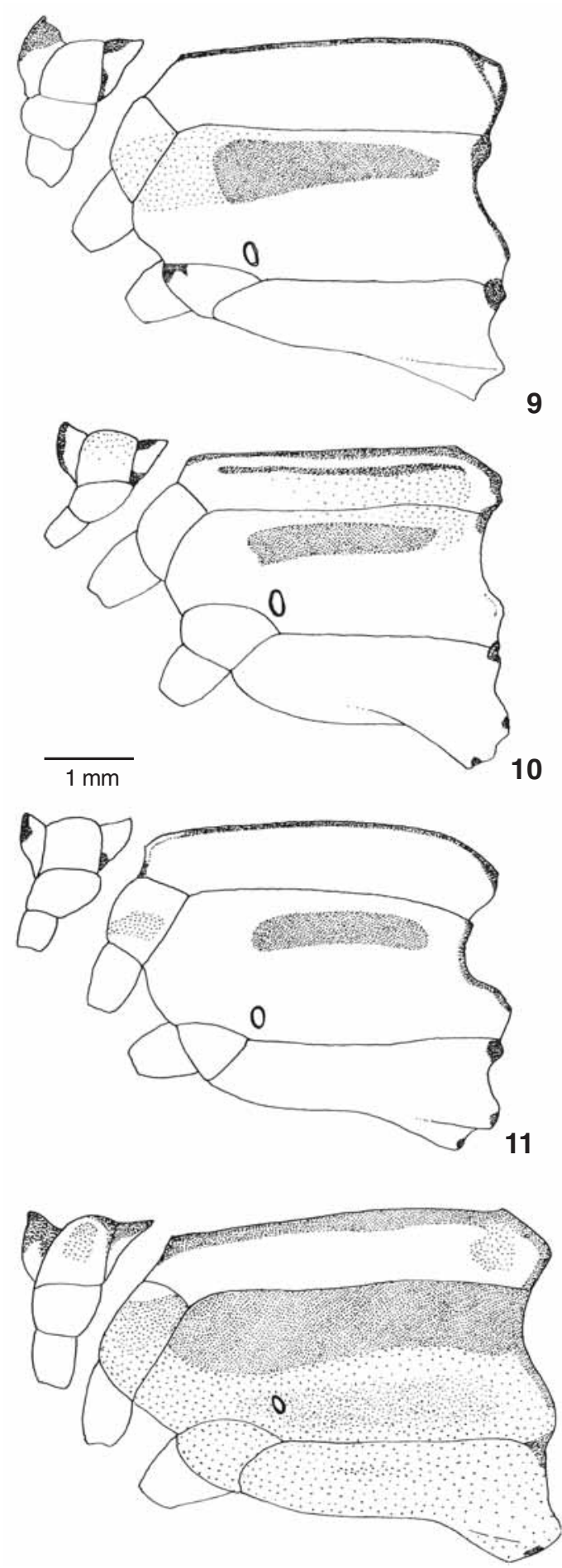
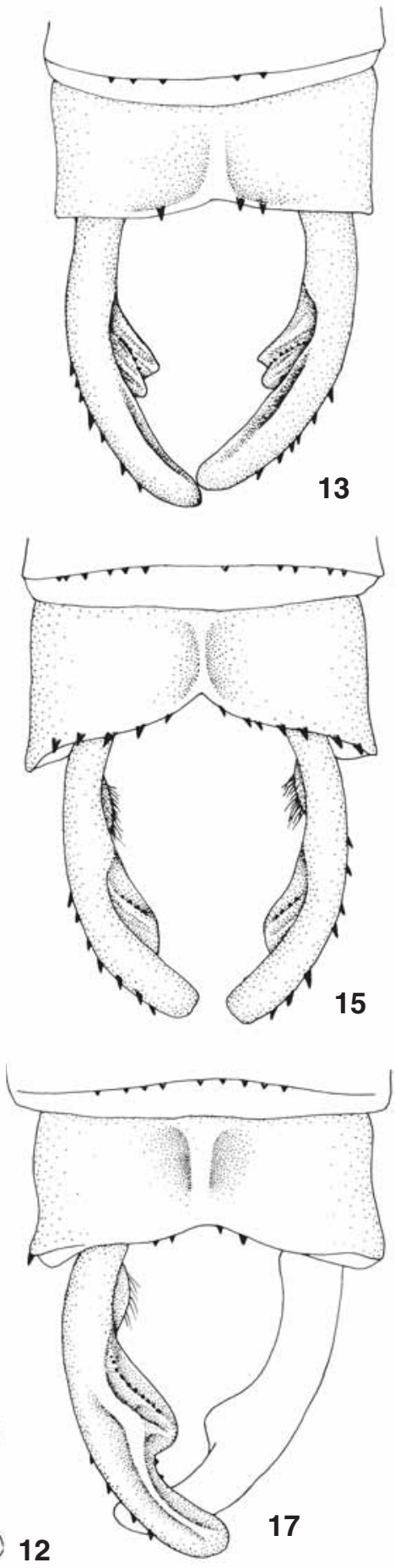

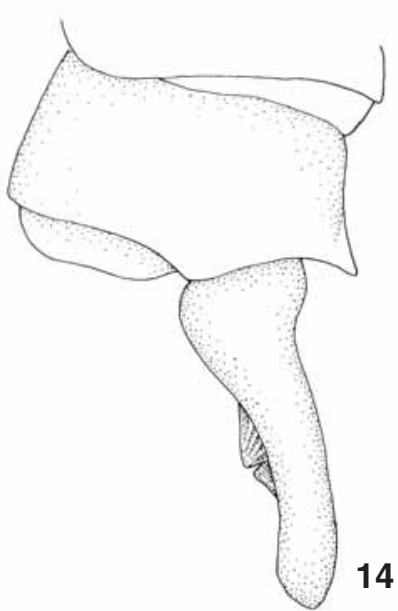

14
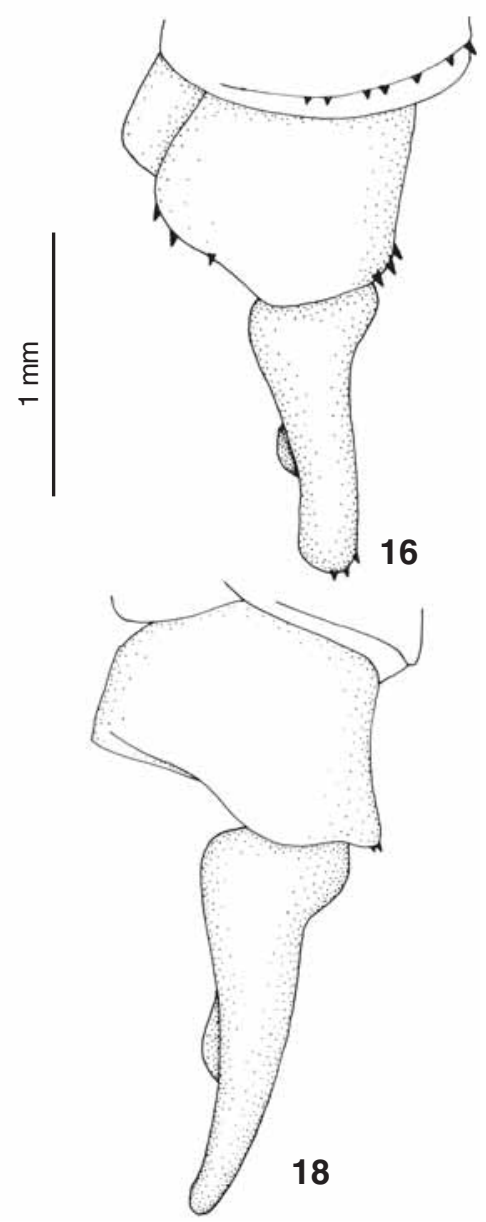

Figures 9-18. (9-12) Thorax in lateral view of the holotype male (9) and female allotype (10) of H. luizfelipei and the holotypes male of H. gracile (11) and H. mantiqueirae (12); (13-18) superior anal appendages of the holotype male of H. luizfelipei in dorsal (13) and lateral (14) views and holotypes male of $\mathrm{H}$. gracile in dorsal (15) and lateral (16) views and holotypes male of $\mathrm{H}$. mantiqueirae in dorsal (17) and lateral (18). 
orange. Venation. Postnodal in forewing 18 (50\%), 19 (25\%), 20 (25\%); in hindwing 15 (25\%), 16 (25\%), 17 (50\%); postquadrangular cells in fore and in hindwings $2(100 \%)$; number of cells below the pterostigma in forewing 2 (25\%), 21 / $2(50 \%), 2 / 3+1+1 / 3(25 \%)$; in hindwing $2(25 \%), 3(25 \%), 1 / 2$ $+1+1 / 2(50 \%)$; fore and hindwings petiolated beyond the base of the quadrangle.

Abdomen. Segments 1-2 ligth orange with the dorsum black and a middorsal yellow line on the second. Segments 37 four banded i.e.with a proximal light orange or yellow (paratype) ring, followed by a long dark area, then by a ligth orange or yellow (paratype) area and then by a distal black area. Segment 8 reddish orange except for a dorsal black area occupying its proximal half. Segment 9-10 reddish brown, the latter with a middorsal keel black. In the paratype the pale colors of segments 8-10 are light orange. Appendages reddish brown shading to brown and black toward the apex. Inferior appendages absent.

Structural characters. Posterior prothoracic lobe smoothly convex (Fig. 8). Superior appendages in lateral view (Fig. 18) slightly swollen ventrally at base, this part hollow; in dorsal view (Fig. 17) forcipated with the apex of the medial process about $3 / 5$ of the appendage length, smoothly curved. Basoventral lobe with the margin hairy.

Measurements (mm). Abdomen (with appendages) 38.6; abdomen maximum width (segment 9) 1.7; minimum width (segment 4) 0.8; Hindwing 30.5; pterostigma (radial side) 1.4.

Material examined. Holotype male. Brazil, São Paulo: Campos do Jordão (State Park of Campos do Jordão, 1600 m), 25-I-1992, Mielke leg. Paratype: locality as above, no date, K. Lenko leg. Holotype deposited in collection A.B.M. Machado in Belo Horizonte, Minas Gerais, paratype deposited in the collection of the Department of Zoology, University of Minas Gerais, Brazil.

Female. Unknown.

Etymology. Name refers to the Serra da Mantiqueira, where the specimens were collected.

Remarks. Heteragrion mantiqueirae belongs in species group 2 of SELYS (1862) and runs out to couplet C ${ }^{1}$ of WILLIAMSON'S (1919) key to males, along with $\mathrm{H}$. triangulare and $\mathrm{H}$. beschkii. It differs from $\mathrm{H}$. triangulare as defined by WILLIAMSON (1919) and CALVERT (1909) by having the mesepisternum largely pale and the posterior prothoracic lobe virtually black whereas in $\mathrm{H}$. triangulare the mesepisternum is largely black and the posterior prothoracic lobe pale with a definite round black spot. It differs from $\mathrm{H}$. beschkii by having the anterior and posterior prothoracic lobes largely black (pale in beschkii). Heteragrion mantiqueirae differs from $\mathrm{H}$. ochraceum by characters given in table I. Since the characters given to H. ochraceum by SELYS (1862) are only those that would allow its separation from $\mathrm{H}$. beschkii, it can be concluded that $\mathrm{H}$ ochraceum, like $\mathrm{H}$. beschkii, has the top of head largely pale and, therefore, very different from the dominantly black head of $\mathrm{H}$. mantiqueirae. Heteragrion mantiqueirae differs from $\mathrm{H}$. macilentum by the pattern of black marks in the top of head and by having the posterior prothoracic lobe virtually black, whereas in macilentum it is pale. The superior appendages of mantiqueirae are also different from those of macilentum.

\section{Heteragrion dorsale Selys, 1862 Figs 19-21}

Holotype male. Head (Fig. 19). Labium orange white, labrum light orange with a small round basocentral brownish spot; genae, mandible base and anteclypeus brownish orange; postclypeus black with a brownish orange lateral spot at each side. Anterior portion of frons brownish orange with a central triangular black mark. Posterior part of frons brownish orange with a black central hourglass-shaped black mark. Top of head black with a three branched orange mark, one branch directed antero-medially, another postero medially, and a third one laterally. A poorly defined dot at the postocular area. Scape and pedicel of the antennae dark brown. Rear of the head orange yellow.

Thorax (Figs 19 and 20). Prothorax black except for a cshaped brownish orange mark at the median lobe. Pterothorax (Figs 19 and 20). M episternum orange with black marks as follows: at the middorsal, basal and antealar carinae extending below to the acrotergal area and above to the antealar sinus; a semicircular spot adjoining the upper $1 / 4$ of the humeral suture. A narrow stripe adjoining the middorsal carina at each side visible only at its upper third, extending laterally to the lower third of the antealar carina (Fig. 19). Mesepimeron with a black stripe occupying all the extent of the sclerite, continuing below into the mesinfrepisternum (Fig. 19). It has a brownish orange area at its lower extremity. Small one at the anterodorsal part. Mesinfrepisternum black with a brownish orange anterodorsal part becoming brownish orange at its lower extremity and continuing below into the metinfrepisternum (Fig. 20); a metepimeral one, black becoming brownish orange at its upper extremity. Legs brownish yellow. Wings hylaine, venation and pterostigma brown. Venation. Postnodal in forewing 17; in hindwing 14,17. Posquadrangular cells in fore and hindwings 2 . Number of cells below the pterostigma in forewing $2,2+1+1 / 3$, in hindwing $2,21 / 2$. Fore and hinwings petiolated beyond the base of the quadrangle.

Abdomen. Segments 1-2 laterally orange white, dorsally black, Segments 3-6 (Fig. 21) four banded i.e. with a proximal light orange ring, followed by a long dark area, then by a grayish orange area and then by a black distal ring. Segment 7 dark with a proximal light orange ring. Segments 8-10 lacking.

Measurements (mm). Abdomen (segments 1-7) 32.5; hindwing up to the level of pterostigma 23.9; pterostigma (radial side) 1.5 .

Material examined. Holotype male. The specimen lacks abdominal segments 8-10, virtually all left forewing, the apex (after pterostigma) of all wings, the forelegs and left middleg. 

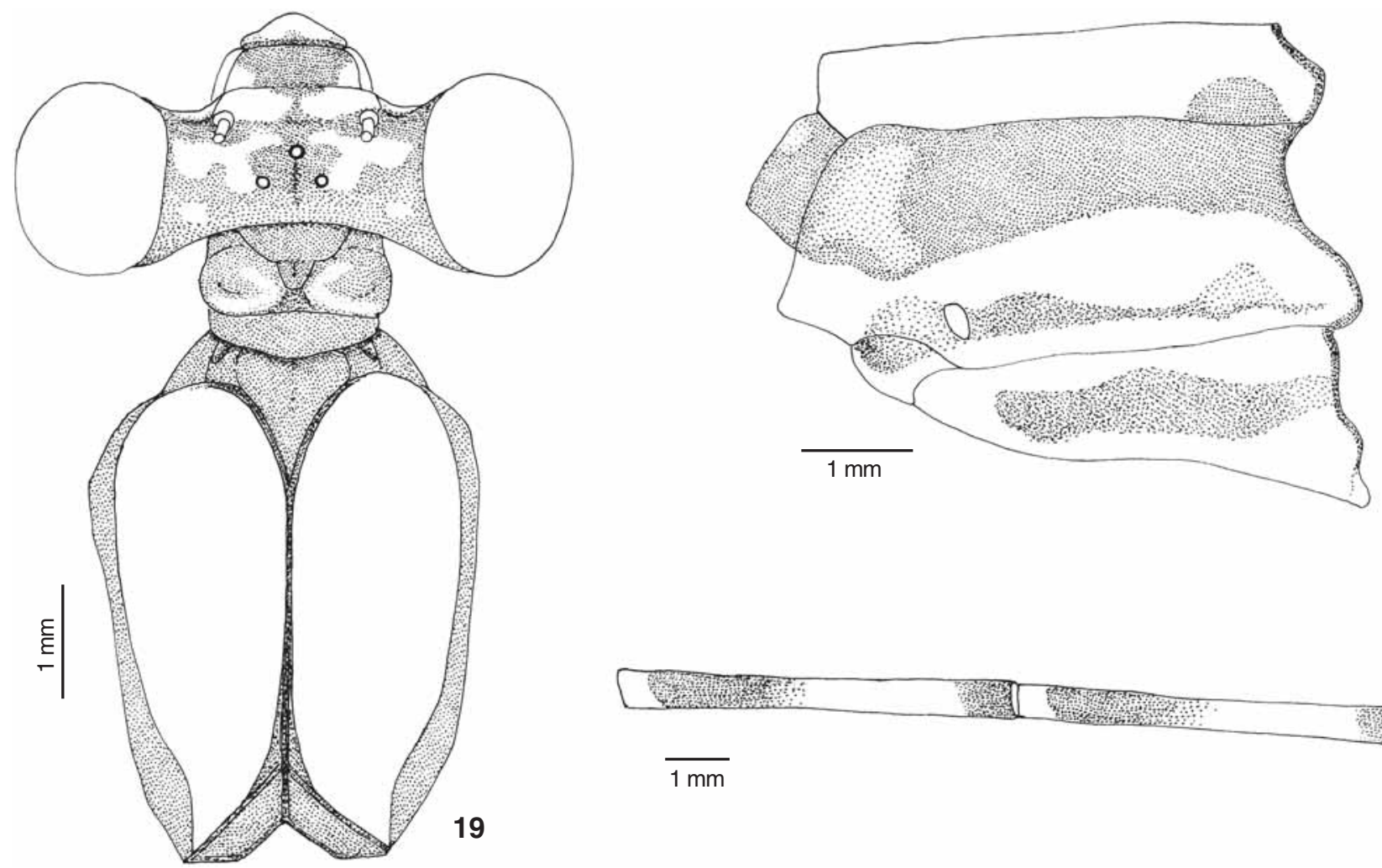

Figures 19-21. Heteragrion dorsale, holotype male, head and thorax in dorsal (19) view, thorax in lateral view (20) and abdominal segment 3, 4 .

The head, prothorax and right forewing are in an envelope attached to the pin. The abdominal segments 3-7 are glued to segment 2. The following labels are attached to the pin: a large green label " $\mathrm{H}$. dorsale"; a large white label "Heteragrion flavidorsale D.S. Bresil"; a small green label Paule B.G.. All Iabels are in Selys' handwrighting, Paul B.G. stands for Paul de Borchgrave, a Belgian count who lived in Nova Friburgo, Rio de Janeiro. The label corresponds well with the data in SELYS (1862) where one reads: “Nouvelle-Friburg, au Brésil (M. le comte Paul de Borchgrave). Collect. Selys "The white label indicates that Selys initially thought to name the species flavidorsale and latter changed to dorsale.

Remarks. The above redescription agrees basicaly with the original description made by SeLYs (1862) and adds more information to it. In what concerns the pale colors however, there are disagreements. SELYS (1862) describes the episternum as being "jaune d'ocre vif" and says that $\mathrm{H}$. dorsale is a very distinct species by having the whole fore part of thorax living yellow. Indeed the white label indicates that initially he named the species flavidorsale. Nevertheless we described the mesepisternum of $\mathrm{H}$. dorsale as being orange, more precisely color 5A 6 of the Methuen Handbook of Colour (KoRnERup \& WANSCHER 1967). The labrum and the anterior part of frons are described by SelYs (1862) as being yellow and we found them light orange (6 A4) and brownish orange (7 C) respectivelly. The pterostigma is described as black and we found it brown. Unfortunatelly the holotype lacks the abdominal segments 810 and the appendages, that were lost after being described by SELYS (1862). It is not known why Menger did not draw the $H$. dorsale holotype. The fact is that $\mathrm{H}$. dorsale was known to WILLIAMSON (1919) only from the descriptions and was not included in his key where it would run out to couplet $\mathrm{C} 1$ together with $\mathrm{H}$. triangulare and $\mathrm{H}$. beschkii. Heteragrion dorsale differs from $\mathrm{H}$. triangulare by having the mesepisternum orange whereas in $\mathrm{H}$. triangulare it is largely black. It differs from $\mathrm{H}$. beschkii by the head and prothorax largely black, pale in beschkii. LENCIONI (2005) contains original drawings of the appendages and pterothorax of an Heteragrion species presumed to be $\mathrm{H}$. dorsale but it is certainly not, since the pleural black striping is very different. In Lencioni's species there is only one pleural stripe at the mesepimeron, whereas in the "true" $\mathrm{H}$. dorsale there are two additional stripes at the metepisternum and metepimeron. In the "true" $\mathrm{H}$. dorsale the mesepimeral black stripe is continuous and occupies all the extension of the sclerite continuing into the mesinfraepisternum and, therefore, very different from that of the species figured by LENCIONI (2005). 


\section{ACKNOWLEDGEMENTS}

I am indebted to Myrian Morato Duarte for the drawings illustrating this article and to Lúcio Cadaval Bedê for critically reviewing this manuscript.

\section{REFERENCES}

Calvert, P. 1909. Contribution to a knowledge of the odonata of the neotropical region exclusive of Mexico and Central America. Annals of the Carnegie Museum, Pittsburg, 6: 73-280.

CostA, J.M. 1978. Revisão do gênero Oxyagrion Selys, 1876 (Odonta, Coenagrionidae). Publicações Avulsas do Museu Nacional do Rio de Janeiro, Rio de Janeiro, 61: 1-213.

De M ARM ELS, J. 1987. On the type specimens of some neotropical Megapodagrionidae, with a description of Heteragrion pemon sp.n. and Oxystigma caeruleans sp.n. from Venezuela (Zygoptera). Odonatologica, Bilthoven, 11 (3): 225-238.

De Marmels, J. 2004. Heteragrion makiritari sp.nov. with descriptions of hitherto unknown females and larvae of other species from Venezuela (Odonata: M egapodagrionidae, Lestidae). International Journal of Odonatology, Reutlingen, 7 (3): 439-458.

Donnely, T.W. 1965. Heteragrion eboratum a new species of damselfly from Guatemala (Odonata: M egapodagrionidae). Proceedings of the Entomological Society of Washing- ton, Washington, 17: 96-100.

Kornerup, A. \& J.H. Wanscher. 1967. Methuen Handbook of color. London, Methuem, 243p.

LENCIONI, F.A.A. 2005. Damselflies of Brazil. An illustrated identification guide $I$. The non-Coenagrionidae families. São Paulo, All Print Editora, 324p.

MACHADO, A.B.M. 1988. Heteragrion petiense spec.nov., from the state of Minas Gerais, Brazil (Zygoptera: Megapodagrionidae). Odonatologica, Bilthoven, 17 (3): 267-274.

Rıs, F. 1918. Libellen (Odonata) aus der Region der amerikanischen Kordilleren von Costa Rica bis Catamarca. Archiv für Natürgeschichte, Berlin, 82 (9): 1-192.

Selys-Longchamps, E. 1862. Synopsis des Agrionines. Bulletin de l'Academie Royale de Belgique, Bruxelles, 6: 1-42.

Selys-Longchamp, E. 1886. Revision du Synopsis des Agrionines. Mémoire Couronnés de L'Academie RoyaledeSciences des Lettres et des Beauxarts de Belgique, Bruxelles, 38: 1-233.

SJÖSTEDT, Y. 1918. Wissenschafilishe Ergebnisse der schwedischen entomologischen Reise des Herr. Dr. A. Roman in Amazonas 1914-1915 I Odonata. Arkiv für Zoologi, Stockholm, 11 (15): 1-54.

Williamson, E.B. 1919. Results of the University of MichiganWilliamson Expedition to Colombia (1916-1917). IV. Notes on species of the genus Heteragrion Selys, with descriptions of new species (Odonata). Occational Papers of the Museum of Zoology, Ann Harbor, 68: 1-66.

Received in 29.XI.2005; accepted in 13.X.2006. 